\title{
Tanulmány
}

\section{A METÁN METAMORFÓZISA, A CSEPPFOLYÓSÍTOTT FÖLDGÁZ}

\section{METHAMOPHOSIS OF METHANE, THE LIQUEFIED NATURAL GAS}

\author{
Reményi Károly \\ az MTA rendes tagja
}

\begin{abstract}
ÖSSZEFOGLALÁS
A földgázigény erősen növekszik, amit a széles körű kereslet, bőséges, alacsony költségű ellátás és a világszerte egyre növekvő gázellátás támaszt alá, ezt a cseppfolyósított földgáz (LNG) növekvő kínálata is segíti. A világ földgázkészleteinek jelentős hányada földrajzilag elkülönül az energiafelhasználóktóktól. A csővezetéken történő szállítás nagy mennyiségű állandó kereslet és rövidebb távolság esetén hatékony. Az LNG-export kapacitása tovább növekszik az ázsiai kereslet növekedése és az amerikai földgázárak versenyképessége következtében. Azonos tömegű, gázhalmazállapotú földgáz térfogatának az LNG körülbelül 1/600-a.
\end{abstract}

\section{ABSTRACT}

Demand on natural gas increases strongly, supported by extensive demand, plentiful low-cost supplies, and the increasing availability of gas globally, aided by the growing supplies of liquefied natural gas (LNG). A significant part of the world's natural gas reserves is geographically separate from energy users. Transportation by pipeline is efficient for high volumes of consistent demand and shorter distances. LNG export capacity increases further as a result of growing Asian demand and US natural gas prices remaining competitive. LNG takes up about $1 / 600^{\text {th }}$ the volume of equal mass natural gas in the gaseous state.

Kulcsszavak: energia, földgáz, cseppfolyós földgáz, metán, klímaváltozás

Keywords: energy, natural gas, liquefied natural gas, methane, climate change 


\section{A VILÁG ÁLTALÁNOS ENERGIAHELYZETE}

Az utóbbi évszázadban az energiahordozók felhasználása között jelentős arányeltolódások voltak. Az 1800-as évek közepétől közel száz évig a szén gyakorlatilag egyeduralkodó energiaforrás volt, majd váltakozó mértékben helyet kért a kőolaj, az atomenergia, a földgáz, és napjainkban egyre jelentősebb mértékkel a megújuló energia.

A kőolaj valamivel több mint a harmadát adja a világ teljes energiafelhasználásának. A szén részesedése 2017-ben 27,6\% volt. A földgáz egyre fontosabbá válik, két éve már $23,4 \%$ volt a részesedése. A vízenergia szerepe alig változik, az atomenergiáé pedig váltakozó. A vízenergián kívüli megújulók (szél, geotermikus, nap, biomassza, hulladék) gyors térnyerése figyelhető meg, ami 2017ben még így is csak 3,6\%-os részesedéshez vezetett. Bár csökken az olaj és a szén relatív súlya, a felhasznált mennyiség jellemzően így is nő, mert közben a teljes energiatermelés gyarapszik.

2017-ben a világ energiafelhasználása 2,2\%-kal nőtt, ami 2013 óta a leggyorsabb ütem. A földgáz fogyasztása nőtt leginkább, 83 millió tonna olajegyenértékkel $(1$ toe $=11630 \mathrm{kWh}$ ), amelyet a megújulók (plusz 69 millió toe, a bio üzemanyagokkal együtt 72 millió toe) és az olaj (plusz 65 millió toe) követett. A szén felhasználása 25,5 millió toe-vel nőtt, a vízenergiáé 5,3 millió toe-vel, az atomé 5,2 millió toe-vel. Az energiaforrások szerepét jelentőse befolyásolta az utóbbi évtizedekben igen jelentős erőt képviselő környezetvédő mozgalom, illetve az adott energiahordozó használata által keletkező környezetszennyezés. Első lépésként megoldották a kénszennyezési problémát, majd a nitrogén-oxidok jelentős csökkentésében értek el eredményeket. Napjainkban a helytelenül (!) gyakran szennyezőnek nevezett szén-dioxidra terelődött a figyelem, és az energetikai fejlesztésekkor a $\mathrm{CO}_{2}$-kibocsátás csökkentése gyakorlatilag első számú szempontként szerepel. Így az energetikában a fosszilis tüzelőanyagok csökkentése alapvető célkitüzéssé vált. Ezt a problémát számos cikkünkben elemeztük, és nem kívánunk most az energetika és a klímaváltozás általános problémáira kitérni. Az energiahordozók közötti arányok alapján nyugodtan kijelenthetjük, hogy a fosszilis energiahordozók szerepe a következő évtizedekben is alapvető marad, bármilyen nagy ívü célkitüzésekkel gondolják más energiahordozókkal kiváltani. A fosszilisok aránya $80 \%$ felett van, tehát ennek kiváltása néhány évtized alatt, bármely más energiával, enyhén szólva is komolytalannak mondható. 


\section{A FÖLDGÁZ ELŐRETÖRÉSE}

A fosszilis energiahordozókon belül a földgáz térnyerése várhatóan növekedni fog, mert a használata kényelmi és egyéb szempontok alapján, például a fajlagosan kis szén-dioxid-kibocsátási értékkel nagyon előnyös. Viszont a felhasználása során több metán kerül a légkörbe, amelynek az üvegházhatás kialakulásában betöltött szerepe lényegesen (kb. hússzorosan) meghaladja a szén-dioxidét.

A földgázt világszerte szívesen használják, de a szénnel ellentétben a földi régiók szerinti eloszlása nagyon egyenlötlen. Az elmúlt években a földgáztartalékok jelentősen nőttek, mert a világ számos részén fedeztek fel új lelőhelyeket, illetve az új technológiai eljárások lehetővé tették a meglévő tartalékok növelését.

A földgázlelőhelyek és a fogyasztók közötti jelentős távolságok miatt a szállítás alapvető problémává lépett elő. Természetes megoldás a csővezeték, de előjött a kontinensek közötti szállítás szükségessége is, amikor tenger/óceán választja el a forrást és a fogyasztót. Kisebb távolságra, kb. 4000 km távolságon belül és sekély tengereknél szóba jön még a csővezeték, de nagyobb távolságoknál, és mélyebb tengereknél már más megoldást kellett keresni. Itt merült fel, hogy gáznemü helyett cseppfolyós állapotban kerüljön sor a távolságok áthidalására. Mivel Magyarországon is felmerült a cseppfolyós földgáz vásárlásának lehetősége, érdemes a teljes rendszert áttekinteni. Az 1. táblázatban a legnagyobb földgáztartalékkal rendelkező államok és Magyarország helyzete látható (URL1).

1. táblázat. A legnagyobb földgáztartalékkal rendelkező államok

\begin{tabular}{|l|c|c|}
\hline \multicolumn{1}{|c|}{ Ország } & Bizonyított földgáztartalék (milliárd $\mathbf{m}^{\mathbf{3}}$ ) & Év \\
\hline Oroszország & 47800 & 2017 \\
Irán & 33500 & 2017 \\
Katar & 24300 & 2017 \\
Amerikai Egyesült Államok & 8700 & 2016 \\
Szaúd-Arábia & 8600 & 2017 \\
Magyarország & 8 & 2017 \\
\hline
\end{tabular}

(A földgáz bizonyított tartalékai: az adott év december 31-én éjfélkor geológiai és mérnöki adatokkal bizonyított földgázkészletek) (URL1)

A 2. táblázat (URL2) a 2017. évi tartalékok és a kitermelés figyelembevételével (R/P, Reserve/Production) bemutatja, hogy az egyes régiók milyen hosszú időtartamra elegendö készlettel rendelkeznek. 
2. táblázat. A földgáztartalékok régiónkénti eloszlása (R/P, év) (URL2)

\begin{tabular}{|l|c|}
\hline \multicolumn{1}{|c|}{ Régió } & (év) \\
\hline 1. Közel-Kelet & 120 \\
2. Oroszország és az utódállamok & 72 \\
\hline 3. Afrika & 63 \\
4. Dél- és Közép-Amerika & 45 \\
\hline 5. Ázsiai és Csendes-óceáni Gazdasági Együttmüködés & 30 \\
6. Európa & 12 \\
7. Észak-Amerika & 10 \\
\hline
\end{tabular}

A földgáz nagy nyomású szárazföldi vezetékes szállításakor a nagy távolság (a szállítóvezetéki kompresszorok hajtásához szükséges nagy energiaigény) miatt a cseppfolyós állapotú gázszállítás kerül elötérbe. A legnagyobb LNG-importőrök Japán, Dél-Korea, Kína, India, Spanyolország, Tajvan és Nagy-Britannia voltak. A két utóbbi ország jelentős mennyiséget importál csővezetéken is. A legnagyobb exportőrök (az értékek millió tonnában): korábban: Katar (76,39), Malajzia (23,72), Ausztrália $(20,88)$, Nigéria $(19,58)$, Indonézia $(18,97)$, Trinidad $(13,48)$, Algéria $(11,21)$, Oroszország $(10,86)$. Az LNG piaca gyorsan változik, és egyre újabb szereplők jelennek meg: jelenleg tizenkilenc ország exportál LNG-t, új eladó a piacon Brunei, Guinea, Peru, az USA és Ausztrália. Oroszország gyors ütemben fejleszti LNG-termináljait. Az USA 2012-ben már nagyjából nettó exportőr lett földgázban, és az exportjának jelentős része LNG-formában volt. Rotterdamban már megjelentek az amerikai LNG-tankerek, és hazánkban is szóba került amerikai LNG vásárlása.

A földgáz-kereskedelem erősen növekszik, amelyet széles körü kereslet, bőséges, alacsony költségủ ellátás és a világszerte egyre növekvő gázellátási igény jellemez. A növekedést segíti a cseppfolyósított földgáz (LNG) növekvő kínálata, és ezért a kereskedelemben is az LNG részarányának növekedését tervezik (URL3). A földgázfelhasználás éves növekedési ütemére 2040-ig átlag 1,7\% növekedést terveznek, ami 40-50\%-os igénynövekedést jelent. Szám szerint a 2017-es 3700 milliárd m³-röl 2040-ben az igény kb. 5370 milliárd m³-t ér el. A távolsági szállítás (cső+LNG) 2040es 670 milliárd $\mathrm{m}^{3}$-éböl 550 LNG-formában és 120 csövön, gáz formában várható.

Az LNG árazására három modellt használnak:

- Olajár-indexálás: elsősorban Japán, Dél-Korea, Kína használja ezt a modellt. Az árat a fütőolaj és a gázolaj tőzsdei ára határozza meg.

- Olajár-indexálás és másik energiahordozó (szén vagy villamos áram) tőzsdei ára: ez a formula általában Európában divatos. 
- Piaci (tőzsdei) ár: a vezetékes földgáz amerikai tőzsdei árához kapcsolják az LNG árát, föleg az USA és az Egyesült Királyság területén.

Az LNG árát a tőzsdei folyamatok mellett az LNG minősége is befolyásolja, továbbá az olajárak változásával is változik (URL4).

A jövőben tehát a gázigény jelentős részét a kereskedelemben LNG-vel elégítik ki. Az alapanyag a földgáz, amelynek összetevői:

$\begin{array}{ll}\text { metán }\left(\mathrm{CH}_{4}\right) & 97 \% \\ \text { etán }\left(\mathrm{C}_{2} \mathrm{H}_{6}\right) & 0,919 \% \\ \text { propán }\left(\mathrm{C}_{3} \mathrm{H}_{8}\right) & 0,363 \% \\ \text { bután }\left(\mathrm{C}_{4} \mathrm{H}_{10}\right. & 0,162 \% \\ \text { szén-dioxid }\left(\mathrm{CO}_{2}\right) & 0,527 \% \\ \text { oxigén }\left(\mathrm{O}_{2}\right) & 0-0,08 \% \\ \text { nitrogén }\left(\mathrm{N}_{2}\right) & 0,936 \%\end{array}$

nemesgázok: Ar, He, Ne, nyomelemként Xe

Nagyon fontos, hogy az egyéb szénhidrogének ,éghetőségi” alsó határértékei (flammability limit, LFL) alacsonyabbak a földgázénál, illetve az LNG gőzénél, például a benziné $1,4 \%$, a propáné $2,1 \%$, a földgázé pedig 5\%. Az ólommentes benzin gyulladási hőmérséklete kb. $260{ }^{\circ} \mathrm{C}$, a gázturbina üzemanyag kissé nagyobb, mint $204^{\circ} \mathrm{C}$. A propán és bután keverékéé a keverési aránytól függően $482-593{ }^{\circ} \mathrm{C}$, míg a földgázé $593-650{ }^{\circ} \mathrm{C}$.

A szabadba kiömlő LNG elpárolgásakor csupán gőz képződik, a levegővel keveredve különböző koncentrációjú zónák keletkezhetnek. Egyes helyeken elérve a gyulladási határértéket, meggyulladhatnak. Ez még nem jelent feltétlenül robbanást is, csak égést, de robbanás is létrejöhet. A szabadban a metán égésének terjedési sebessége kicsi, kb. 4m/h (Reményi, 2013).

Az LNG jellemzői:

- az LNG forráspontja atmoszférikus nyomáson: $-160{ }^{\circ} \mathrm{C}$ és $-163{ }^{\circ} \mathrm{C}$ közötti érték,

- párolgási hője: $212,9 \mathrm{~kJ} / \mathrm{kg} \mathrm{K}$,

- az LNG visszagázosítására $510 \mathrm{~kJ} / \mathrm{kg}$ és $577 \mathrm{~kJ} / \mathrm{kg}$ közötti értékeket találunk $\left(-162{ }^{\circ} \mathrm{C}\right.$-ról $\sim 10{ }^{\circ} \mathrm{C}$-ra $)$.

Az LNG sűrüsége függ az összetételétől, és $420-470 \mathrm{~kg} / \mathrm{m}^{3}$ között változik, néha eléri az $520 \mathrm{~kg} / \mathrm{m}^{3}$ értéket. A hőmérséklet szerinti változás gradiense $1,4 \mathrm{~kg} / \mathrm{m}^{3} / \mathrm{K}$. Egy tonna LNG elpárologtatásával kb. $1400 \mathrm{~m}^{3}$ gázt kapunk. 
A gázszolgáltatók $34 \mathrm{MJ} / \mathrm{m}^{3}$ fütőértékkel számolnak. Az LNG energiatartalma $22,5 \mathrm{MJ} / \mathrm{dm}^{3}$, fajlagos tömege $450 \mathrm{~kg} / \mathrm{m}^{3}$, tehát kb. $50 \mathrm{MJ} / \mathrm{kg}$. Az energiatartalom szempontjából $1 \mathrm{~kg}$ LNG egyenértékü $0,6 \mathrm{~kg}$ dízellel, illetve $0,7 \mathrm{~kg}$ benzinnel (URL5).

A biztonsági elöírások egyre szigorodnak az LNG mind nagyobb előtérbe kerülésével. 1965 és 2008 között huszonöt baleset történt az LNG gyártása, tárolása és szállítása során.

\section{A TELJES LNG-IPAR}

A teljes LNG-rendszernek öt lényeges eleme van:

- a földgáz feltárása és kitermelése,

- a földgáz cseppfolyósítása az exportterminálban és a hajókba töltése,

- az LNG elszállítása az igénylőhöz,

- az LNG lefejtése és tárolása az importterminálban,

- visszagázosítás és a fogyasztóhoz való szállítás.

\section{AZ LNG GYÁRTÁSA}

A földgázt előtisztítása után alapvetően négy, kismértékben különböző eljárás egyikével alakítják LNG-vé. Mindegyik eljárás lényege a gáz többfokozatú komprimálása és hütése:

- legelterjedtebb a kevert hütésü (Mixed Refrigeration) C3MR- vagy APCI-eljárás,

- második legismertebb a kaszkád eljárás,

- a DMR kettős hütőkörü eljárást a Shell alkalmazza,

- a Linde cég által kidolgozott eljárást a cégről nevezték el.

A mechanikai hütési körben (kevert hütésü eljárás) propánt, etánt, metánt, nitrogént stb. alkalmaznak. A Joule-Thompson-elvnél, amikor a gáz egy szelepen, nagy nyomáscsökkentéssel áramlik keresztül izentalpikus folyamatban (állandó entalpia), a kis nyomáson a hőmérséklete lecsökken. Ezt Joule-Thompson-folyamatnak nevezik, a szelepet JT-szelepnek. Gázexpanziós turbinás eljárásnál a nagy nyomású gázt egy (centrifugális vagy axiális) turbinában expandáltatjuk, a turbina hajt egy berendezést is, a gáz izentropikus (állandó entrópiájú) folyamat során nagymértékben lehủl. A Linde-eljárás alapelve megegyezik az előbbiekkel, csak a hütés hatását egy speciális ellenáramú hütővel javítja (URL6). 
A modern kor jellegzetes veszélyforrásai, a nagy tömegben, óriási energiamennyiséget jelentő tüzelőanyag-szállítások és -tárolások. Ilyenek például a folyékony földgázt kezelő terminálok, amelyek városok közelében helyezkednek el, de ilyenek a szállítóhajók is. A folyékony földgáz a meghibásodott berendezésből a szabadba kerül és elpárolog, nagy területen szétterjed, majd az égéshez szükséges megfelelő oxigénkoncentrációt elérve meggyullad, esetleg felrobban. Az LNG nagy energiasürüsége miatt a szállítóhajókon óriási energiamennyiség halmozódik fel. Ez úgy érzékelhetö, ha összevetjük például a Hirosimában felrobbantott atombombából felszabadult energia mennyiségével. A bomba 15 kt TNT (trinitrotoluol) energiamennyiséget tartalmazott, ez 62,7 terajoule-nak felel meg. Egy LNG-vel feltöltött $147000 \mathrm{~m}^{3}$-es tanker hötartalma 3308 terajoule. Egy ilyen, közepes tanker tehát kb. ötvenhárom hirosimai bombának megfelelő energiát képvisel. (Az eddigi legnagyobb atombomba-kísérlet során felszabadult energia ezt jelentősen meghaladta: $50 \mathrm{Mt}$ TNT, azaz $2,1 \times 1017$ joule volt).

Óriási LNG-katasztrófák ismeretesek, bár nem sok ilyenre volt példa. 1944. október 20-án Clevelandben (Ohio, USA) a kelet-ohiói földgázgyártó vállalatnál meghibásodott egy LNG-tartály. A baleset során 128 ember halt meg a robbanásban és a tüzben. A tartály - amelynek nem volt biztonsági gátfala - még a második világháború alatt készült, amikor a felhasznált fém mennyiségének ellenőrzése nagyon szigorú volt. A tartály acélja kevés nikkel ötvözőanyagot tartalmazott, így a tartály anyaga az LNG kriogén körülményei között nagyon törékeny volt. A tartály megrepedt, az LNG a város csatornarendszerébe ömlött, és szétterjedt; elpárolgott, gőzzé, gázzá alakult, amely égett, és fel is robbant. A Clevelandet elborító LNG-tüz (URL4) borzalmas pusztítást végzett.

\section{LNG-TERMINÁLOK}

Az LNG-export- és importtermináljai közötti különbség a cseppfolyósítás, illetve az újragázosítás folyamata.

Az exportterminálban a földgáz cseppfolyósításához nagy kriogén hütőberendezésekre van szükség. Speciális, drága szerkezeti anyagok és kenőanyagok szükségesek. Jelentős a villamos energia fogyasztása.

Az importterminálban nagy méretü hőcserélők szükségesek, amelyekben a folyadék felmelegedve ismét gázhalmazállapotba kerül.

Az LNG-export- és importterminálokban lényegében egyformák a tankerkikötők, a kriogén folyadékszivattyúk és a szigetelt tárolótartályok. A tárolótartályok talán a legcsereképesebb berendezések az export- és importterminálok tekintetében, ha netalán feladatváltozásra kerül sor (URL7). 


\section{AZ LNG SZÁLLÍTÁSA}

Az LNG-t rövid távolságra, kisebb mennyiségben a cseppfolyós levegőnél alkalmazott eszközökkel lehet szállítani. Az LNG szállítását nagy mennyiségben és hosszabb távolságra tankhajókkal végzik. Egy tankhajóban több tartályban összesen 100-250 ezer $\mathrm{m}^{3}$ folyadék helyezhető el. A tartályok belső fala legalább 9\% nikkelt tartalmazó minőségi acél, amely ellenáll az extra alacsony hömérsékletnek, a folyadék hidrosztatikai nyomásának és a folyadék feletti gáztér mintegy 0,5 bar nyomásának.

A földgázvezetékekben és a létesítményekben az átlag áramlási sebesség $20 \mathrm{~m} / \mathrm{s}$. A csővezetékben a maximális sebességet a rendelkezésre álló nyomás határozza meg, de a vezérlő és biztonsági szelepekben $100 \mathrm{~m} / \mathrm{s}$ is engedélyezhető. Csővezetékeken LNG-t nem exportálnak, bár a kb. hatszázszoros fajtérfogatarány jelentős méretkülönbséget jelentene. Az LNG-csővezetékek és -szerelvények drágák, a fejlesztésük folyamatos. Az LNG áramlási sebességét 1,5-3 m/s értékek között választják. Rövid távú LNG-szállításra rendelkezésre állnak csővezetékek, például az LNG-nek a hajókról a szárazföldi tárolásra történő szállításához. Folyamatban van a hosszabb csővezeték tervezése, amely lehetővé tenné a hajók számára, hogy távolabb maradjanak a kikötői létesítményektől.

\section{KÖVETKEZTETÉSEK}

Az elmúlt évtizedek állandóan növekvő energiafelhasználásában túlnyomóan a fosszilis energiahordozók nagy aránya uralkodott. A megújulók, az atomenergia és az egyéb energiahordozók óriási befektetésekkel, váltakozva növelték részesedésüket, de döntő szerepet esetleg csak egyes országokban tudtak elérni. Nagyon valószínü, hogy néhány évtized alatt nem lehet kiszorítani a fosszilis energiahordozókat, hacsak valami teljesen új energiaforrást nem fedeznek fel. A fosszilisokon belül abszolút értékben mennyiségileg mindegyik nőtt, de a szén részaránya csökkent, és a földgáz szerepe jelentősen növekedett. A szénhidrogének kimerülésére általában hatvan-hetven évet becsülnek, de mindig új tartalékokat tárnak fel, és a kimerülés várható ideje már évtizedek óta csúszik. Valóságos kimerülés esetén újra előtérbe kerülne a szén, amelyböl több száz éves tartalék van. A megújulóknál az energia tárolása nincs megoldva, és a kis energiasúrüség miatt egyébként óriási földfelületet igényelnek. A földgázforrások geológiailag egyenlőtlen eloszlása miatt kulcskérdéssé vált a szállítás. Néhány ezer kilométer távolságra még megoldás a csővezeték, de kontinensek között elönyösebb a földgázt cseppfolyós formában (LNG) szállítani. Az elkövetkező évtizedek földgáz-kereskedelemében az LNG-forma jelentős előretörését várják, amelyben ha- 
zánk is érintett. Az LNG-ipar számos új technikai megoldást igényel, és fokozott biztonsági intézkedések kidolgozását is. Az új gázipar veszélyes, de a veszély eltúlzása nem indokolt.

\section{IRODALOM}

Reményi K. (2013): A tüz örök. Budapest: Akadémiai Kiadó

Wu, J. et al. (2007): A Realistic Dynamic Modeling Approach to Support LNG Plant Compressor Operations. LNG Journal, October, 27. https://pdfs.semanticscholar.org/889b/ e041d29eed5d39068e4d7ce79d8f5249cd5f.pdf?_ga=2.153908984.1756541174.1563185513240194266.1562240455

URL1: Natural Gas - Proved Reserves. In: The World Factbook. https://www.cia.gov/library/publications/the-world-factbook/rankorder/2253rank.html

URL2: Full report - BP Statistical Review of World Energy 2018. https://www.bp.com. statistical-review/bp-stats-review-2018-full-report, https:/www.bp.com/content/dam/bp/business-sites/en/global/corporate/pdfs/energy-economics/statistical-review/bp-stats-review-2018-fullreport.pdf

URL3: Energy Economics. https://www.bp.com/en/global/corporate/energy-economics/energyoutlook/demand-by-fuel/natural-gas.html

URL4: LNG Tankers - LNG Carriers. https://timrileylaw.com/LNG_OPPOSITION.htm

URL5: LNG-CNG és Metán (CH4) összehasonlitása. dieselgaz.eu/2015/09/20/lng-cng-es-metan-ch4-osszehasonlitasa

URL6: LNG R\&D for the Liquefaction and Regasification Processes - Oil\&Gas. www.oil-gasportal.com/lng-rd-for-the-liquefaction-and-regasification

URL7: LNG Carrier. https://en.wikipedia.org/wiki/LNG_carrier 